\title{
Expression of Toll-Like receptors in metabolic syndrome: A systematic review
}

$$
\text { Manijeh Mahdavi }{ }^{1}, \text { Zahra Fallah }^{2,3^{*}} \text {, Roya Kelishadi }{ }^{2}
$$

1. Pediatric Inherited Diseases Research Center, Research Institute for Primordial Prevention of Non-Communicable disease, Isfahan University of Medical Sciences, Isfahan, Iran

2. Department of pediatrics, Child Growth and Development Research Center, Research Institute for Primordial Prevention of Non-Communicable Disease, Isfahan University of Medical Sciences, Isfahan, Iran

3. Students' Research Center, Isfahan University of Medical Sciences, Isfahan, Iran

*Corresponding author:Tel: +98 9103983425 Fax: +98 3136687898

Address: Research Institute for Primordial Prevention of Non-Communicable Disease, Afarinesh Building, Isfahan University of Medical Sciences, Po. Box: 81745-319, Hezarjerib Street, Isfahan, Iran

E-mail: z_fallah@mail.mui.ac.ir

Received: 2017/12/31 revised: 2018/02/24 accented: 2018/05/18

\section{Abstract}

Introduction: Toll-Like Receptors (TLRs) of innate immune system have documented roles in the pathogenesis of metabolic disorders. This study aims to systematically review the expression of TLRs on metabolic syndrome (MetS).

Materials and methods: We systematically searched PubMed/Medline, ISI web of Science, Scopus, Google Scholar, EMBASE, and OVID databases until February 2017. The terms "Metabolic Syndrome” OR “Mets" AND "Toll like receptor" OR "Toll like” OR "TLRs" OR "TLR" were used. "Expression" advertently was not used in our search and was considered in the selection process. Three steps for selecting the articles and then their qualification were conducted.

\section{Results:}

First, 1373 articles were found in the international databases. After removing duplicates, 963 papers remained and after two steps of selection, this number reached 410 and then 27, respectively. After full text screening and qualifying processes, we finally included 13 articles consisting of five animal and eight human studies. All human studies reported overexpression of TLRs (types 2, 4, 5,9) in MetS, and most animal studies documented an increased TLRs expression.

Conclusion: This systematic review provides evidence for the relation of innate immune system with MetS. Its findings regarding overexpression of special TLRs (e.g. types 2, 4, 5, 9) in MetS and their basic mechanisms and clinical implications might be investigated in further studies.

Keywords: Metabolic Syndrome, Toll-Like Receptors, Chronic disease, Inflammation

\section{Introduction}

Metabolic syndrome (MetS) is defined as coincidence of metabolic disorders including dyslipidemia, abdominal obesity, hypertension and insulin resistance/glucose intolerance (1). It has emerged as a worldwide epidemic and major public health care concern with an increasing prevalence rate (2). In addition to its high prevalence rate, the importance of MetS is because of its association with worldwide

Copyright (C) 2018 Journal of Basic Research in Medical Science. This is an open access article distributed under the terms of the Creative Commons Attribution 4.0 International License (https://creativecommons.org/licenses/by/4.0/) which permits copy and redistribute the material, in any medium or format, provided the original work is properly cited. 
epidemics of diabetes, cardiovascular diseases and nonalcoholic fatty liver disease (NAFLD) (3, 4). Many studies have proposed that conditions as MetS, atherosclerotic cardiovascular disease, insulin resistance, and obesity are associated with the activation of innate immune system. Latest evidence suggests that much of this association can be traced to a unique family of pattern recognition receptors known as Toll-Like receptors (TLRs) (5-8).

TLRs are trans-membrane receptors that are widely expressed in immune, epithelial and endothelial cells. Most of these receptors are on the cell surface, except for TLR $3,-7,-8$, and -9 , which mainly are in the endosomes and lysosomes (9). Briefly, TLR activation promotes inflammatory signaling cascade, phagocytosis, oxidative burst and eventually insulin resistance (10, 11). Important agonists that trigger TLR activity are saturated fatty acids, endotoxins, oxidized LDL, and damageassociated molecular patterns (12-14). It is suggested that targeting the TLRs pathway may be an effective method to help treating these disorders (15).

Large body of evidence exists on the role of TLRs in each of the aforementioned disorders $(16,17)$, but limited experience is available on pooled information about MetS. This systematic review aims to provide the most recent data about the TLR types expressed in the context of MetS.

\section{Materials and methods}

Outcome/ Measures definition: The primary outcome in the current review was the expression (qualitative and quantitative) of TLRs in every cell/tissue and at every level .

Search strategy: We searched international databases until February 2017. We considered PubMed/Medline, ISI web of Science, Scopus, Google Scholar, EMBASE and OVID without limiting for age range, time, and language.
The following terms were used: "Metabolic Syndrome", OR “Mets" AND "Toll like receptor", OR "Toll like", OR "TLRs" OR "TLR". We did not include "expression" in the search terms, and we looked for it at screening stages. We used MeSH term for MetS in PubMed/Medline search, built search strategies and also looked at the reference list of retrieved articles. Search strategy in PubMed was as follows: (("metabolic syndrome"[All Fields] OR "metabolic syndrome x"[All Fields]) OR MetS [All Fields]) AND ((("toll like receptor"[All Fields] OR "toll like"[All Fields]) OR TLRs [All Fields]) OR TLR [All Fields]).

Inclusion and exclusion criteria: We included all experimental (in vivo, in vitro, interventional) and observational studies. We looked at baseline data of trials to find any expression data appropriate for extraction. We considered both human and animal studies. In the case of finding multiple publications from one study, we selected the more comprehensive one or considered them together.

Selection process: At the first step, the retrieved titles were screened to find relevant articles. Next, the abstracts were screened, and finally the full texts of the recovered papers were screened.

Quality assessment: Our study eligibility criteria, design of studies, sample sizes, measurement methods and estimates were considered to qualify the papers. Two independent reviewers (ZF and $\mathrm{MM}$ ) qualified the articles and the poor- rated ones were excluded.

Data extraction: The data related to authors, publications features, study population, methods, values of selected measures and main conclusions were extracted.

\section{Results}

The search algorithm displaying the number of initial search results and included studies is shown in Figure 1. At the first step, 1373 articles were found in the international databases. After the 
duplicate removal and further two steps of screening processes, 963, 410 and 27 articles were remained respectively. As presented in Table 1, after full text screening and qualifying processes, 13 articles were eligible to be included in final review. (6, 18-29) Altogether, these thirteen studies consisted of eight human studies (18-20, 22, 25-28) with a total population of 732 patients (at least $70 \%$ females, with total age range of 15 years and above), as well as five animal studies (mice/murine models) $(6,21,23,24,29)$.

As presented in Table 2, all human studies displayed increased expression of one or more type of TLRs in the monocytes of MetS patients. The most prevalent types of the receptor with increased expression in humans were TLR 2, 4 and 9.

Three studies on animal models of MetS showed a controlling/regulating role for TLRs especially TLR 9 (21) and TLR 5 $(24,29)$. Another two studies showed overexpression of TLR 2 (6) and increase in a related protein named Janus Kinase 3(JAK3) in signaling cascade of TLRs (23).

\section{Discussion}

Based on the results analyzed, our systematic review revealed uniformly increased expression of TLRs in the context of MetS both in humans and animal models. The main TLRs involved were the types $2,4,5$ and 9 .

Several studies have shown that TLRs are possible links between obesity /visceral fat accumulation and inflammation and their consequent effects on body tissues $(30,31)$. Konner and colleagues reported that upon development of obesity, numerous molecular conditions might promote activation of stress kinases, causing peripheral insulin as well as central insulin and leptin resistance (10). Jang and colleagues in their study concluded that TLR-2 in vascular endothelium mediates some pro-inflammatory and "unfolding protein response", which results in impairment of vaso-dilatory effect of insulin and ends in endothelial dysfunction (32). Thompson et al. suggested that continued activation of TLR might result in vascular oxidative stress and thereby would aggravate the process of hypertension and heart failure (33). These links would ultimately result in cardio-metabolic disorders (8) which are common consequences of MetS. Our findings propose some molecular mediators in their pathways.

McMillan et al found that in the mice with over-expression of muscular TLR-4, highfat diet significantly decreases fatty acid oxidation in muscles in accordance with increased body weight and fat, glucose intolerance, and cellular oxidative damage (34). Frisard et al showed that activation of TLR-4 by lipo-polysaccharides would result in increased glucose consumption and reduced fatty acid oxidation in skeletal muscles (35). These findings suggest that TLR-4 plays an important role in the metabolic reactions in skeletal muscle. This might explain MetS related metabolic disturbances in muscles. Some lipopolysaccharide endotoxins, originating from gut microbiome, are secreted into blood, and by activating TLRs, lead to a chronic metabolic inflammation status called meta-inflammation (36-38). This is a core pathogenic process in the development of MetS. Our study refers to some TLRs involved in this situation. As is evident from the articles systematically reviewed in this study, many aspects of the relation between TLRs and metabolic/endocrine disorders are well documented. Himes et al showed that mice lacking TLR-2 are substantially protected from diet-induced adiposity, insulin resistance, hypercholesterolemia, and hepatic steatosis (6). Cuevas et al speculated that there is a positive feedback between the expression of TLR4, myeloid differentiation primary response gene 88(MYD88) and plasminogen activator inhibitor-1(PAI-1) in the adipose tissue of obese individuals that develop metabolic complications (18). 


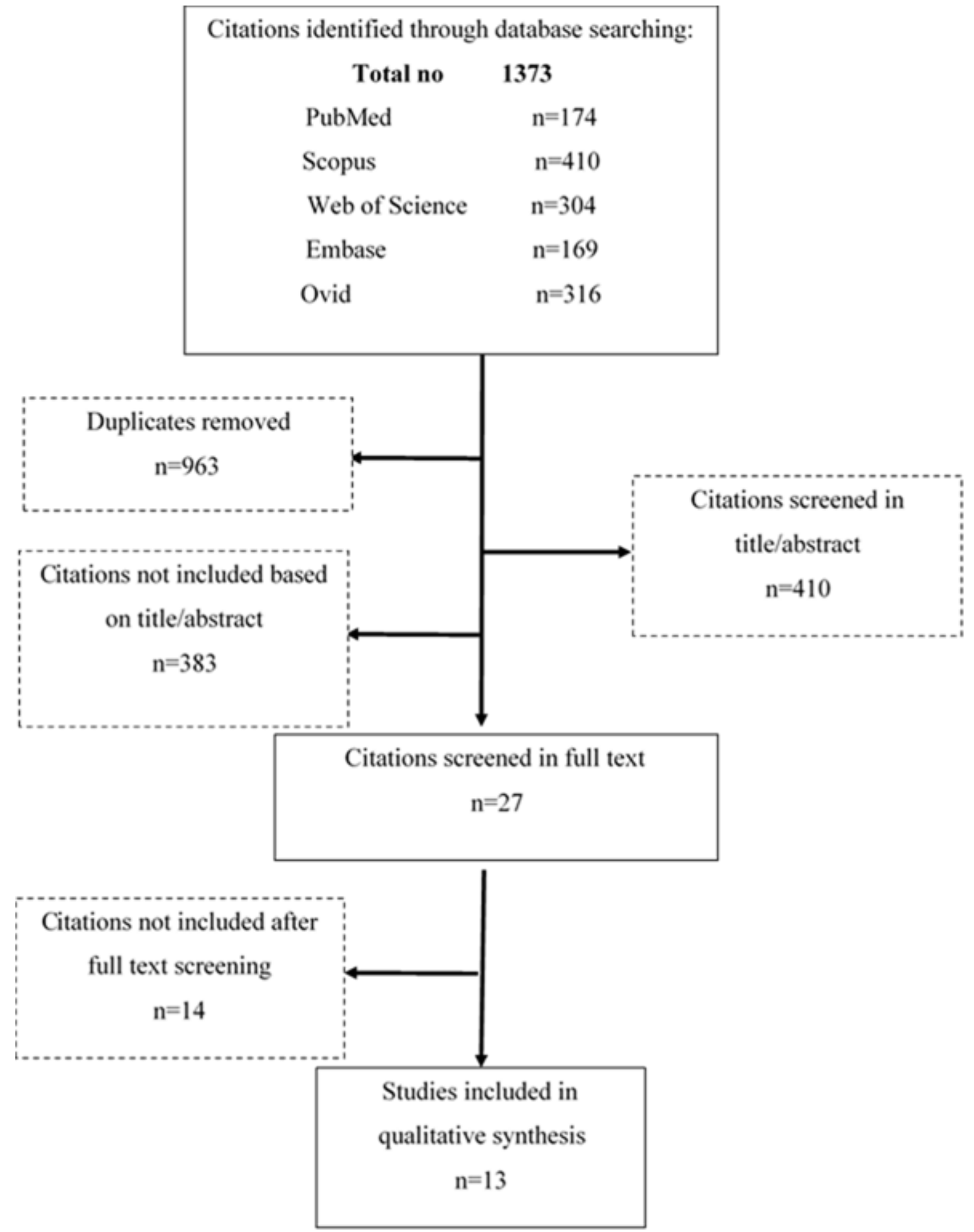

Figure 1. Flowchart of the review. 
Table 1. Characteristics and findings of the Studies included in the qualitative synthesis

\begin{tabular}{|c|c|c|c|}
\hline $\begin{array}{l}\text { First author, study } \\
\text { year }\end{array}$ & Type of study & Population & Main conclusions \\
\hline Cuevas AM, $2017^{18}$ & $\begin{array}{l}\text { Prospective } \\
\text { study }\end{array}$ & $\begin{array}{l}40 \text { obese men and women, with BMI between } 30 \text { and } \\
45 \mathrm{~kg} / \mathrm{m} 2 \text { at a single hospital (Clinica Las Condes) in } \\
\text { the city of Santiago, Chile }\end{array}$ & $\begin{array}{l}\text { A significant correlation between the gene expression of TLR } 4 \text { in subcutaneous fat with } \\
\text { the subcutaneous and visceral expression of MYD88. }\end{array}$ \\
\hline Zwolak A, $2016^{19}$ & $\begin{array}{l}\text { Experimental } \\
\text { cohort study }\end{array}$ & $\begin{array}{l}48 \text { individuals, all Caucasians of Polish descent, who } \\
\text { had never been treated due to liver diseases before } \\
\text { control group comprised } 22 \text { healthy individuals }\end{array}$ & $\begin{array}{l}\text { A significant association between NAFLD and BMI, MetS and inflammatory parameters, } \\
\text { and TLR4. } \\
\text { TLR4 expression in peripheral blood mononuclear cells was increased in overweight and } \\
\text { NAFLD individuals with metabolic syndrome compared to control groups }\end{array}$ \\
\hline Devaraj S, $2015^{20}$ & $\begin{array}{l}\text { Experimental } \\
\text { study }\end{array}$ & $\begin{array}{l}\text { Subjects aged } 21-70 \text { years with MetS }(n=45) \text { and } \\
\text { healthy control subjects }(n=37) \text { from Sacramento } \\
\text { County, California }\end{array}$ & $\begin{array}{l}\text { Increased endosomal TLR-9 expression in Mets compared to controls that correlate with } \\
\text { increased nuclear NFkB expression in the monocytes of these subjects, with no change in } \\
\text { TLR3 protein. }\end{array}$ \\
\hline Hong CP, $2015^{21}$ & $\begin{array}{l}\text { Experimental } \\
\text { study }\end{array}$ & Mice & $\begin{array}{l}\text { TLR9 signaling involved in regulating adipose tissue inflammation and controlling } \\
\text { obesity and Mets. }\end{array}$ \\
\hline Jialal I, $2015^{22}$ & $\begin{array}{l}\text { Experimental } \\
\text { study }\end{array}$ & $\begin{array}{l}\text { Subject aged } 21-69 \text { years, with nascent MetS }(\mathrm{n}=28) \\
\text { and control subjects }(\mathrm{n}=25) \text { from Sacramento } \\
\text { County, California. }\end{array}$ & $\begin{array}{l}\text { There was a significant increase in Adipose Tissue (AT) TLR2 and TLR4 protein in } \\
\text { MetS compared to controls. }\end{array}$ \\
\hline Mishra J, $2015^{23}$ & $\begin{array}{l}\text { Experimental } \\
\text { study }\end{array}$ & Mice & $\begin{array}{l}\text { The essential role of JAK3 in promoting mucosal tolerance through suppressed } \\
\text { expression and limiting activation of TLRs thereby preventing intestinal chronic low } \\
\text { grade inflammation (CLGI) and associated obesity and Mets. }\end{array}$ \\
\hline Chassaing B, $2014^{24}$ & $\begin{array}{l}\text { Experimental } \\
\text { study }\end{array}$ & Mice & $\begin{array}{l}\text { Similar to previous studies from TLR- } 5 \text { null mice. These mice had Mets and more prone } \\
\text { to develop colitis compared to their sibling controls. }\end{array}$ \\
\hline Jialal I, $20144^{25}$ & $\begin{array}{l}\text { Experimental } \\
\text { study }\end{array}$ & $\begin{array}{l}\text { Subjects aged 21-69 years with nascent MetS }(n=37) \\
\text { and healthy controls }(n=32) \text { from Sacramento County, } \\
\text { California. }\end{array}$ & SCD14 reflects increased monocyte TLR-4 protein and activity in nascent Mets. \\
\hline Orsatti CL, 201426 & $\begin{array}{l}\text { Cross-sectional } \\
\text { experimental } \\
\text { study }\end{array}$ & $\begin{array}{l}1 \text { Brazilian women (age } \geq 45 \text { years and amenorrhea } \geq 12 \\
\text { months } 31\end{array}$ & $\begin{array}{l}\text { TLR-2 and TLR- } 4 \text { expressions were associated with increased pro-inflammatory } \\
\text { cytokines, IL- } 6 \text { and TNF-a, with no association with biomarkers of MetS }\end{array}$ \\
\hline Hardy OT, $2013^{27}$ & $\begin{array}{l}\text { Experimental } \\
\text { study }\end{array}$ & $\begin{array}{l}17 \text { adolescents (three boys and fourteen girls) } \\
\text { between } 15 \text { and } 19 \text { years from the University of } \\
\text { Massachusetts Worcester and Boston campuses }\end{array}$ & $\begin{array}{l}\text { Their study suggest that activation of TLRs may be partially responsible for the } \\
\text { increased systemic inflammation seen in adolescents with Mets }\end{array}$ \\
\hline Jialal I, $2012^{28}$ & $\begin{array}{l}\text { Experimental } \\
\text { study }\end{array}$ & $\begin{array}{l}\text { Subjects aged }(21-70 \text { years }) \text { with MetS }(n=49) \text { and } \\
\text { healthy control subjects }(n=41) \text { from Sacramento } \\
\text { County, California }\end{array}$ & $\begin{array}{l}\text { They make the novel observation that both TLR } 2 \text { and TLR } 4 \text { expression and activity are } \\
\text { increased in the monocytes of patients with Mets and could contribute to increased risk } \\
\text { for diabetes and CVD. } \\
\text { This study provides novel data of increased TLR- } 2 \text { and } 4 \text { in Mets serving }\end{array}$ \\
\hline Himes RW, $2010^{6}$ & $\begin{array}{l}\text { Experimental } \\
\text { study }\end{array}$ & Mice & $\begin{array}{l}\text { The obesity and other chemical features of Mets can be prevented in TLR-2 deleted mice } \\
\text { using two physiologically relevant diet models. }\end{array}$ \\
\hline Vijay-Kumar M, $2010^{29}$ & $\begin{array}{l}\text { Experimental } \\
\text { study }\end{array}$ & Mice & $\begin{array}{l}\text { The malfunction of the innate immune system (in this study TLR- } 5 \text { deficient mice) } \\
\text { may promote the development of Mets. }\end{array}$ \\
\hline
\end{tabular}


Table 2. Summary of the main findings of studies included in the review.

\begin{tabular}{|c|c|c|c|}
\hline & First author, study year & TLRs activation & Tissue/cells \\
\hline \multirow{4}{*}{ छ } & $\begin{array}{c}\text { Jialal I, 2012 } \\
\text { Jialal I,2015 } \\
\text { Orsatti CL, 2014 } \\
\end{array}$ & TLR2 and $4 \uparrow$ & Monocytes \\
\hline & Hardy OT, $2013^{27}$ & TLRs $\uparrow$ & Monocytes \\
\hline & $\begin{array}{c}\text { Zwolak A, 2016 } \\
\text { Jialal I, 2014 } \\
\text { Cuevas AM, 2017 } \\
\text { Cus }\end{array}$ & TLR4 $\uparrow$ & Monocytes and adipose tissue \\
\hline & Devaraj S, $2015^{20}$ & TLR9 $\uparrow$ with no changes in TLR3 & Endosomal, monocytes \\
\hline \multirow{4}{*}{ : } & Hong CP, $2015^{21}$ & TLR9 for regulating role & Adipose tissue \\
\hline & Himes RW, 2010 & TLR2 $\uparrow$ & $\begin{array}{l}\text { Liver and Primary epididymal } \\
\text { adipose tissue }\end{array}$ \\
\hline & Mishra J, 2015 & JAK3 for signaling cascade of TLRs $\uparrow$ & Frozen colon tissue \\
\hline & $\begin{array}{l}\text { Vijay-Kumar M, 2010 } \\
\text { Chassaing B, 2014 }\end{array}$ & $\begin{array}{l}\text { TLR5 for controlling and regulating } \\
\text { role }\end{array}$ & Proximal colon and adipose tissue \\
\hline
\end{tabular}

Zwolak et al showed that TLR4 expression in peripheral blood mononuclear cells was increased in overweight individuals with metabolic syndrome compared to control groups (19). Devaraj et al demonstrated increased endosomal TLR-9 expression in Mets compared to controls (20).

Hong et al. found a dramatic increase of macrophages as well as $\mathrm{T}$ helper cells in the adipose tissue of TLR-9-deficient mice compared to wild-type mice. They showed that TLR-9 signaling is involved in regulating the inflammation of adipose tissue and controlling obesity and the MetS (21). Jialaland colleagues showed a significant increase in Adipose Tissue TLR2 and TLR4 protein in MetS compared to controls (22). Mishraet al study demonstrates the essential role of JAK3 in promoting mucosal tolerance through suppressed expression and limiting activation of TLRs thereby preventing intestinal chronic low grade inflammation and associated obesity and MetS (23). Chassaingand coworkers showedTLR-5 null mice had Mets and were more prone to develop colitis compared to their sibling controls (24). Jialal et alstudy reflects increased monocyte TLR-4 protein and activity in nascent MetS (25). Orsatti and colleagues showed that TLR-2 and TLR-4 expressions were associated with increased pro-inflammatory cytokines, IL-6 and TNF- $\alpha$, with no association with biomarkers of MetS. (26) Hardy et al study suggests that activation of TLRs may be partially responsible for the increased systemic inflammation seen in adolescents with MetS (27). Jialal and co-researchers made the novel observation that both TLR2 and TLR4 expression and activity are increased in the monocytes of patients with Mets and could contribute to increased risk for diabetes and CVD (28). And finally Vijay-Kumar et al showed thatThe malfunction of the innate immune system (in their study TLR-5 deficient mice) may promote the development of Mets (29). Our systematic review pools and summarizes their findings.

Several other disorders such as autoimmune thyroid and pancreatic diseases and septic dysregulation of the hypothalamic pituitary adrenal axis have been linked to TLR activation (39) and its gene polymorphism (40-42) as well. These receptors have also shown wide range relations with diabetes (43-46) and nonalcoholic fatty liver disease $(47-49,17)$.

On the other hand, Zhang and colleagues reported that environmental circumstances may override the genetic aspects of TLRs and their interaction with gut microbime (50). Based on their suggestion, researchers should consider the environment-induced alterations of gut microbiota as a significant confounding factor in this relation. 
From the multisided interaction of TLRs with every component of MetS, it is anticipated that TLRs have crucial role in the aggregation of the MetS components and their coincidence named MetS. To the best of our knowledge, no previous systematic review has summarized the types of TLRs expressed in MetS.

\section{Study limitations and strengths}

This systematic review considered published data, and not the grey literature. A variety of tissues of interest and methods for observation existed in the included articles. There were no uniform quantitative data to conduct a metaanalysis. The strength of the study is its novelty as a systematic review in this field.

\section{Conclusion}

This systematic review provides thirteen citations which have worked on the expression of TLRs in MetS. From all the data stated, it is apparent that there is constant over-expression of TLR receptors 2, 4, 5 and 9 in the monocytes and some

\section{References}

1. Ramic E, Prasko S, Mujanovic OB, Gavran L. Metabolic syndrome-theory and practicE. Mater Sociomed. 2016; 28(1):71-3.

doi: 10.5455/msm.2016.28.71-73.

2. Miranzadeh-Mahabadi H, Emadi-Baygi M, Nikpour P, Kelishadi R. Association study between metabolic syndrome and rs8066560 polymorphism in the promoter region of sterol regulatory element-binding transcription factor 1 gene in Iranian children and adolescents. Int J Prev Med. 2016; 7:41. doi: 10.4103/2008-7802.177314.

3. Fallah Z, Feizi A, Hashemipour M, Kelishadi R. Effect of fermented camel milk on glucose metabolism, insulin resistance and inflammatory biomarkers of adolescents with metabolic syndrome: A double-blind, randomized, other cells of humans and animals afflicted with MetS. This systematic review confirms the close relation of innate immune system with MetS and proposes the types of TLRs involved. These distinguished TLRs might be used in future studies for developing agents affecting the situation.

\section{Acknowledgment}

This study was done under the funding and support of Isfahan University of Medical Sciences, Iran (grant number 293372). We gratefully acknowledge the authors of reviewed papers for their appreciable work.

\section{Conflict of interest}

None declared.

\section{Author contribution}

All authors contributed to the idea, design and conduct the study and drafting the manuscript. All authors approved the final version to be submitted.

cross-over trial. J Res Med Sci. 2018; 23:32. doi: 10.4103/jrms.JRMS_1191_17.

4. Fallah Z, Feizi A, Hashemipour M, Kelishadi R. Positive effect of fermented camel milk on liver enzymes of adolescents with metabolic syndrome: A double-blind, randomized, cross-over trial. Mater Sociomed. 2018 Mar; 30(1):20-25. doi: 10.5455/msm.2018.30.20-25.

5. Fessler MB, Rudel LL, Brown JM. Toll-like receptor signaling links dietary fatty acids to the metabolic syndrome. Curr Opin Lipidol. 2009; 20(5):379-85. doi: 10.1097/MOL.0b013e32832fa5c4.

6. Himes RW, Smith CW. Tlr2 is critical for diet-induced metabolic syndrome in a murine model. FASEB J. 2010; 
24(3):731-9. doi: 10.1096/fj.09141929.

7. Fresno M, Alvarez R, Cuesta N. Tolllike receptors, inflammation, metabolism and obesity. Arch Physiol Biochem. 2011;117(3):151-64. doi: 10.3109/13813455.2011.562514.

8. Eguchi K, Manabe I. Toll-like receptor, lipotoxicity and chronic inflammation: the pathological link between obesity and cardiometabolic disease. J Atheroscler Thromb. 2014;21(7):629-39.

9. Mogensen TH. Pathogen recognition and inflammatory signaling in innate immune defenses. Clin Microbiol Rev. 2009;22(2):240-73, Table of Contents. doi: 10.1128/CMR.00046-08.

10. Konner AC, Bruning JC. Toll-like receptors: linking inflammation to metabolism. Trends Endocrinol Metab. 2011;22(1):16-23. doi: 10.1016/j.tem.2010.08.007.

11. Fusaru AM, Stanciulescu CE, Surlin V, Taisescu C, Bold A, Pop OT, et al. Role of innate immune receptors TLR2 and TLR4 as mediators of the inflammatory reaction in human visceral adipose tissue. Rom J Morphol Embryol. 2012;53(3 Suppl):693-701.

12. Sunshine H, Iruela-Arispe ML. Membrane lipids and cell signaling. Curr Opin Lipidol. 2017;28(5):408$413 . \quad$ doi: 10.1097/MOL.0000000000000443.

13. Zhang W, Hartmann R, Tun HM, Elson CO, Khafipour E, Garvey WT. Deletion of the Toll-Like Receptor 5 Gene Per Se Does Not Determine the Gut Microbiome Profile That Induces Metabolic Syndrome: Environment Trumps Genotype. PLoS One. 2016;11(3):e0150943. doi: 10.1371/journal.pone.0150943.

14. Oosenbrug $T$, van de Graaff MJ, Ressing ME, van Kasteren SI. Chemical Tools for Studying TLR Signaling Dynamics. Cell Chem Biol. 2017;24(7):801-812. doi: 10.1016/j.chembiol.2017.05.022.
15. Lucas K, Maes M. Role of the Toll Like receptor (TLR) radical cycle in chronic inflammation: possible treatments targeting the TLR4 pathway. Mol Neurobiol. 2013;48(1):190-204. doi: 10.1007/s 12035-013-8425-7.

16. Jialal I, Kaur H, Devaraj S. Toll-like receptor status in obesity and metabolic syndrome: a translational perspective. J Clin Endocrinol Metab. 2014;99(1):39-48. doi: 10.1210/jc.2013-3092.

17. Sharifnia T, Antoun J, Verriere TG, Suarez G, Wattacheril J, Wilson KT, et al. Hepatic TLR4 signaling in obese NAFLD. Am J Physiol Gastrointest Liver Physiol. 2015;309(4):G270-8. doi: 10.1152/ajpgi.00304.2014.

18. Cuevas AM, Lazo M, Zuniga I, Carrasco F, Potter JJ, Alvarez V, et al. Expression of MYD88 in Adipose Tissue of Obese People: Is There Some Role in the Development of Metabolic Syndrome? Metab Syndr Relat Disord. 2017;15(2):80-85. doi: 10.1089/met.2016.0104.

19. Zwolak A, Slabczynska O, Semeniuk J, Daniluk J, Szuster-Ciesielska A. Metformin Changes the Relationship between Blood Monocyte Toll-Like Receptor 4 Levels and Nonalcoholic Fatty Liver Disease-Ex Vivo Studies. PLoS One. 2016;11(3):e0150233. doi: 10.1371/journal.pone.0150233.

20. Devaraj S, Adams-Huet B, Jialal I. Endosomal Toll-Like Receptor Status in Patients with Metabolic Syndrome. Metab Syndr Relat Disord. 2015;13(10):477-80. doi: 10.1089/met.2015.0116.

21. Hong CP, Yun CH, Lee GW, Park A, Kim YM, Jang MH. TLR9 regulates adipose tissue inflammation and obesity-related metabolic disorders. Obesity (Silver Spring). 2015;23(11):2199-206. doi: 10.1002/oby.21215.

22. Jialal I, Devaraj S, Bettaieb A, Haj F, Adams-Huet B. Increased adipose 
tissue secretion of Fetuin-A, lipopolysaccharide-binding protein and high-mobility group box protein 1 in metabolic syndrome. Atherosclerosis. 2015;241(1):130-7. doi 10.1016/j.atherosclerosis.2015.04.814.

23. Mishra J, Verma RK, Alpini G, Meng F, Kumar N. Role of Janus Kinase 3 in Predisposition to Obesity-associated Metabolic Syndrome. J Biol Chem. 2015;290(49):29301-12. doi: 10.1074/jbc.M115.670331.

24. Chassaing B, Ley RE, Gewirtz AT. Intestinal epithelial cell toll-like receptor 5 regulates the intestinal microbiota to prevent low-grade inflammation and metabolic syndrome in mice. Gastroenterology. 2014;147(6):1363-77.e17. doi: 10.1053/j.gastro.2014.08.033.

25. Jialal I, Rajamani U, Adams-Huet B, Kaur H. Circulating pathogenassociated molecular pattern - binding proteins and High Mobility Group Box protein 1 in nascent metabolic syndrome: implications for cellular Toll-like receptor activity. Atherosclerosis. 2014;236(1):182-7. doi:

10.1016/j.atherosclerosis.2014.06.022.

26. Orsatti CL, Petri Nahas EA, NahasNeto J, Orsatti FL, Giorgi VI, Witkin SS. Evaluation of Toll-Like receptor 2 and 4 RNA expression and the cytokine profile in postmenopausal women with metabolic syndrome. PLoS One. 2014;9(10):e109259. doi: 10.1371/journal.pone.0109259.

27. Hardy OT, Kim A, Ciccarelli C, Hayman LL, Wiecha J. Increased Tolllike receptor (TLR) mRNA expression in monocytes is a feature of metabolic syndrome in adolescents. Pediatr Obes. 2013;8(1):e19-23. doi: 10.1111/j.20476310.2012.00098.x.

28. Jialal I, Huet BA, Kaur H, Chien A, Devaraj S. Increased toll-like receptor activity in patients with metabolic syndrome. Diabetes Care.
2012;35(4):900-4. doi: 10.2337/dc112375.

29. Vijay-Kumar M, Aitken JD, Carvalho FA, Cullender TC, Mwangi S, Srinivasan S, et al. Metabolic syndrome and altered gut microbiota in mice lacking Toll-like receptor 5 . Science. 2010;328(5975):228-31. doi: 10.1126/science.1179721.

30. Ahmad R, Al-Mass A, Atizado V, AlHubail A, Al-Ghimlas F, Al-Arouj M, et al. Elevated expression of the toll like receptors 2 and 4 in obese individuals: its significance for obesity-induced inflammation. $\mathbf{J}$ Inflamm (Lond). 2012;9(1):48. doi: 10.1186/1476-9255-9-48.

31. Catalan V, Gomez-Ambrosi J, Rodriguez A, Ramirez B, Rotellar F, Valenti $\mathrm{V}$, et al. Increased tenascin $\mathrm{C}$ and Toll-like receptor 4 levels in visceral adipose tissue as a link between inflammation and extracellular matrix remodeling in obesity. J Clin Endocrinol Metab. 2012;97(10):E1880-9. doi: 10.1210/jc.2012-1670.

32. Jang HJ, Kim HS, Hwang DH, Quon MJ, Kim JA. Toll-like receptor 2 mediates high-fat diet-induced impairment of vasodilator actions of insulin. Am J Physiol Endocrinol Metab. 2013;304(10):E1077-88. doi: 10.1152/ajpendo.00578.2012.

33. Thompson JA, Webb RC. Potential role of Toll-like receptors in programming of vascular dysfunction. Clin Sci (Lond). 2013;125(1):19-25. doi: 10.1042/CS20120673.

34. McMillan RP, Wu Y, Voelker K, Fundaro G, Kavanaugh J, Stevens JR, et al. Selective overexpression of Tolllike receptor-4 in skeletal muscle impairs metabolic adaptation to highfat feeding. Am J Physiol Regul Integr Comp Physiol. 2015;309(3):R304-13. doi: 10.1152/ajpregu.00139.2015.

35. Frisard MI, McMillan RP, Marchand J, Wahlberg KA, Wu Y, Voelker KA, et al. Toll-like receptor 4 modulates 
skeletal muscle substrate metabolism. Am J Physiol Endocrinol Metab. 2010;298(5):E988-98. doi: 10.1152/ajpendo.00307.2009.

36. Jialal I, Rajamani U. Endotoxemia of metabolic syndrome: a pivotal mediator of meta-inflammation. Metab Syndr Relat Disord. 2014;12(9):454-6. doi: 10.1089/met.2014.1504.

37. Vila IK, Badin PM, Marques MA, Monbrun L, Lefort C, Mir L, et al. Immune cell Toll-like receptor 4 mediates the development of obesityand endotoxemia-associated adipose tissue fibrosis. Cell Rep. 2014;7(4):1116-29. doi: 10.1016/j.celrep.2014.03.062.

38. Goralska M, Majewska-Szczepanik M, Szczepanik M. [Immunological mechanisms involved in obesity and their role in metabolic syndrome]. Postepy Hig Med Dosw (Online). 2015;69:1384-404. (Polish)

39. Kanczkowski W, Ziegler CG, Zacharowski K, Bornstein SR. Tolllike receptors in endocrine disease and diabetes. Neuroimmunomodulation. 2008;15(1):54-60.

doi: 10.1159/000135624.

40. Belforte FS, Coluccio Leskow F, Poskus E, Penas Steinhardt A. Tolllike receptor 4 D299G polymorphism in metabolic disorders: a metaanalysis. Mol Biol Rep. 2013;40(4):3015-20. doi: 10.1007/s11033-012-2374-5.

41. Cuda C, Badawi A, Karmali M, ElSohemy A. Polymorphisms in Toll-like receptor 4 are associated with factors of the metabolic syndrome and modify the association between dietary saturated fat and fasting high-density lipoprotein cholesterol. Metabolism. 2011;60(8):1131-5. doi: 10.1016/j.metabol.2010.12.006.

42. Steinhardt AP, Aranguren F, Tellechea ML, Gomez Rosso LA, Brites FD, Martinez-Larrad MT, et al. A functional nonsynonymous toll-like receptor 4 gene polymorphism is associated with metabolic syndrome, surrogates of insulin resistance, and syndromes of lipid accumulation. Metabolism. 2010 y;59(5):711-7. doi: 10.1016/j.metabol.2009.09.015.

43. Ladefoged M, Buschard K, Hansen AM. Increased expression of toll-like receptor 4 and inflammatory cytokines, interleukin-6 in particular, in islets from a mouse model of obesity and type 2 diabetes. APMIS. 2013;121(6):531-8. doi: 10.1111/apm.12018.

44. Li J, Chen S, Qiang J, Wang X, Chen L, Zou D. Diet-induced obesity mediates a proinflammatory response in pancreatic beta cell via toll-like receptor 4. Cent Eur J Immunol. 2014;39(3):306-15. doi: 10.5114/ceji.2014.45940.

45. Prajapati B, Jena PK, Rajput P, Purandhar K, Seshadri S. Understanding and modulating the Toll like Receptors (TLRs) and NOD like Receptors (NLRs) cross talk in type 2 diabetes. Curr Diabetes Rev. 2014;10(3):190-200.

46. Strodthoff D, Ma Z, Wirstrom T, Strawbridge RJ, Ketelhuth DF, Engel $\mathrm{D}$, et al. Toll-Like Receptor 3 Influences Glucose Homeostasis and beta-Cell Insulin Secretion. Diabetes. 2015;64(10):3425-38. doi: $10.2337 / \mathrm{db} 14-0838$.

47. Li D, Wang X, Lan X, Li Y, Liu L, Yi $\mathrm{J}$, et al. Down-regulation of miR-144 elicits proinflammatory cytokine production by targeting toll-like receptor 2 in nonalcoholic steatohepatitis of high-fat-diet-induced metabolic syndrome E3 rats. Mol Cell Endocrinol. 2015;402:1-12. doi: 10.1016/j.mce.2014.12.007.

48. Miura K, Ohnishi H. Role of gut microbiota and Toll-like receptors in nonalcoholic fatty liver disease. World J Gastroenterol. 2014;20(23):7381-91. doi: 10.3748/wjg.v20.i23.7381.

49. Ye D, Li FY, Lam KS, Li H, Jia W, Wang Y, et al. Toll-like receptor-4 
mediates obesity-induced nonalcoholic steatohepatitis through activation of X-box binding protein-1 in mice. Gut. 2012;61(7):1058-67. doi: 10.1136/gutjnl-2011-300269.

50. Zhang W, Hartmann R, Tun HM, Elson CO, Khafipour E, Garvey WT. Deletion of the Toll-Like Receptor 5
Gene Per Se Does Not Determine the Gut Microbiome Profile That Induces Metabolic Syndrome: Environment Trumps Genotype. PLoS One. 2016;11(3):e0150943. doi: 10.1371/journal.pone.0150943. 